Dept. of Vet. Laboratories,

Ministry of Agriculture, Riyadh 11195, Kingdom of Saudi Arabia

\title{
PESTE DES PETITS RUMINANTS AMONG SHEEP AND GOATS IN SAUDI ARABIA IN 2004
}

(With 4 Tables)

By

I.H.A. ABD EL-RAHIM; M.H. ABDEL BAKY;

A.R. HABASHI; M.M. MAHMOUD

and D.M. AL-MUJALII

(Received at 28/12/2004)

$$
\begin{aligned}
& \text { طاعون المجترات الصغيرة في الاغنام والماعز }
\end{aligned}
$$

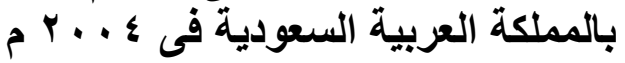

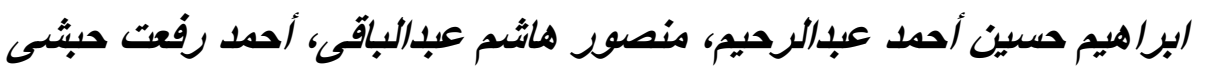

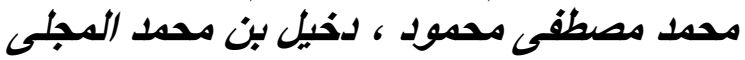

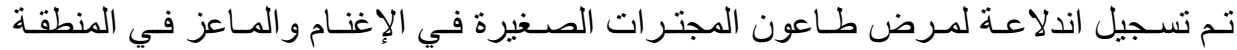

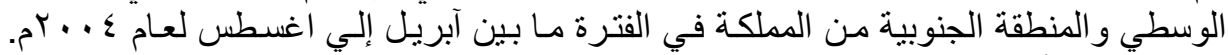

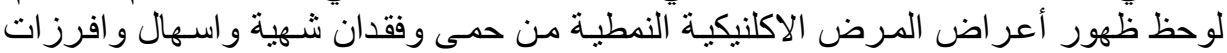

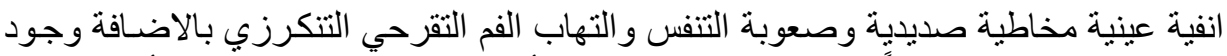

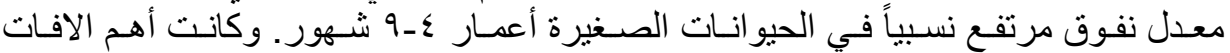

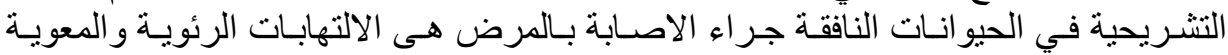

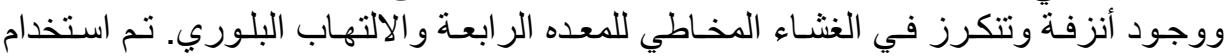

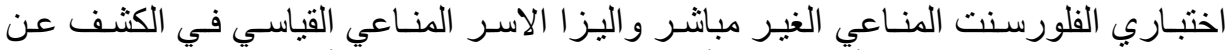

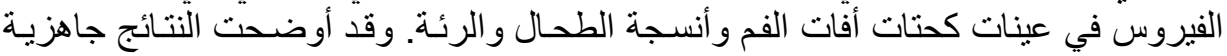

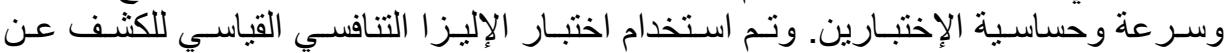

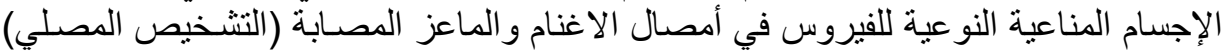

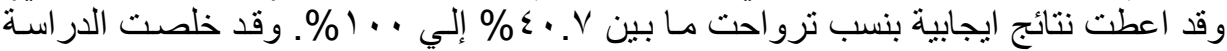

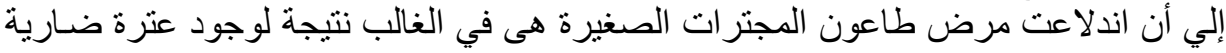

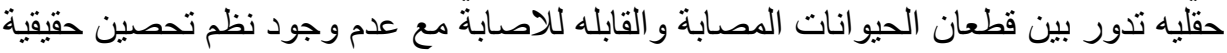

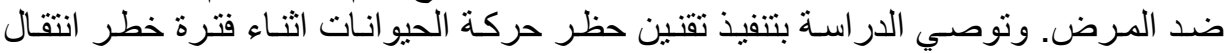

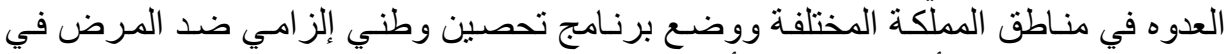

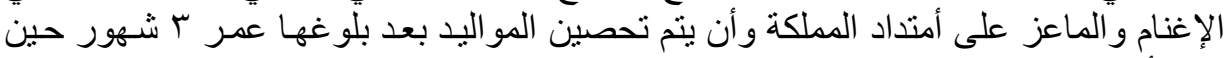
تذني أوتلاشي المناعة الإمية بهاء 
An outbreak of Peste des petits ruminants (PPR) among sheep and goats was reported in the central and southern regions of the Kingdom of Saudi Arabia between April-August 2004. Typical clinical manifestations of acute PPR including, fever, anorexia, diarrhea, mucopurulent nasal and ocular discharges, dyspnea and necro-ulcerative stomatitis were observed with a relatively high case fatality rate among lambs and kids aged 4-9 months. On postmortem examinations, pneumonia, enteritis, hemorrhages and necrosis in the abomasal mucosa, and pleurisy were the most common gross lesions. Both PPRV-antigen and antibody assays were used to confirm diagnosis of the disease. Indirect fluorescent antibody (IFA) technique and immuno-capture ELISA (IC-ELISA) were used for demonstration of PPR viral antigen in the mouth scraping, spleen and lung tissue specimens. The laboratory study indicated that both IFA and IC-ELISA were reliable, rapid and sensitive methods for detection and identification of PPRV antigen. Competitive ELISA (C-ELISA) was used for detection of PPRVantibodies in ovine and caprine sera. Serodiagnosis revealed that 40.7$100 \%$ of the collected sheep and goats sera were positive. In conclusions, the reported PPR outbreak is mostly attributed to the presence of enzootic virulent strains of PPR virus, which could have circulate between the infected and susceptible animals in sheep and goats flocks with no actual national vaccination regime against the disease. The present study recommended that, legalization of the restriction of the animal movement should be applied for sheep and goats populations during the risk period of PPR in different localities of the country. An obligatory vaccination program against PPR virus infection should be applied for all sheep and goats flocks allover the country. Lambs and kids should be vaccinated at $3{ }^{\text {rd }}$ month of age, when the maternal antibodies decline.

Key words: Competitive ELISA (C-ELISA) - Indirect fluorescent antibody (IFA) technique - Immuno-capture ELISA (IC-ELISA) - Outbreak - Peste des petits ruminants $(P P R)-P P R$ virus - Serodiagnosis - Vaccination

\section{INTRODUCTION}

Peste des petits ruminants (PPR) is an acute contagious viral disease of goats and sheep characterized by necrotizing and erosive stomatitis, enteritis and pneumonia. The causative agent, PPRV, is a member of the family Paramyxoviridae and the genus Morbillivirus. Various strains of PPR virus are of one antigenic type (Gibbs, et. al., 
1979). There is existence of a close antigenic relationship between PPR and Rinderpest (RP) viruses (Hamdy, et. al., 1975; Diallo, et. al. 1994).

The disease is prevalent in West Africa, the Middle East and south-west Asia (Taylor, 1984; Taylor, et. al., 1990; Shaila, et. al., 1996). In recent years, PPR has emerged in Turkey (Özkul, et. al., 2002).

PPR is enzootic in Saudi Arabia, outbreaks variably occur in susceptible sheep and goats populations particularly in animals over 4 months and under 1 year of age (Abu-Elzein, et. al. 1990; Al-Naeem, et. al. 2000, Abdel Baky, et. al., 2001). In most countries in which PPR is enzootic, policy of vaccination is considered the most suitable control measure.

There have been several millions of sheep and goats are raising in different localities in Saudi Arabia. Since 2000, the veterinary vaccine production center in Riyadh is unique in annual manufacturing of approximately 4.5-6 million doses of live attenuated vaccine of PPR virus, strain Nigeria 75/1 but almost no actual national park for vaccination against PPR in Saudi Arabia until now has been taken to control the disease in sheep and goats.

The objective of this study is to record the data of epizootiological and virological aspects of PPR during 2004 outbreak and discuss the benefits of organizing national park for vaccination against PPR in different localities in Saudi Arabia for controlling of the disease.

\section{MATERIALS and METHODS}

\section{Epizootiological data}

Data of the most observed clinical signs, postmortem findings, morbidity and case fatality rates, and history of vaccination against PPR in the affected flocks were recorded in details.

\section{Samples for laboratory diagnosis}

Serum samples and tissue specimens from spleen, lung and/or mouth lesions scraping were collected from animals showing clinical signs of PPR pre- and post necropsy. The samples were sent in ice box to the laboratory of veterinary diagnosis in Riyadh where subjected for laboratory investigations for detection of antibodies against PPR virus and for detection of the viral antigen as well as for isolation of the virus.

\section{Preparation of tissue specimens}

Tissue specimens were prepared for virus isolation and detection of the viral antigen. An appropriate peace of chosen affected tissue was cut and washed in cold 0.01 M phosphate buffer saline (PBS), $\mathrm{pH} 7.4$, 
then minced by sterile scissor to very small pieces and homogenized in PBS to prepare 10-20\% tissue homogenate (W/V) using electric homogenizer, Power Gen 125, Fisher Scientific USA. During the homogenization process, the container of the homogenate was kept cold by dipping in ice path. The homogenate was then sieved via four layers of sterile wet gauze and centrifuged at $3000 \mathrm{rpm}$ for 10 minutes at $4{ }^{\circ} \mathrm{C}$.

The supernatant fluid of the centrifuged homogenate was divided into two portions, the first portion was filtrated via $0.45 \mu \mathrm{m} \varnothing$ Millipore syringe filter, Flowpore, ICN and kept at $-70^{\circ} \mathrm{C}$ until used for PPR virus isolation. While the second portion was used directly for detection of PPR viral antigen by immuno-capture enzyme linked immunosorbent assay (IC-ELISA). Sediment of the centrifuged homogenate was washed twice with PBS through resuspension and centrifugation. The washed cells were dispersed and diluted in appropriate volume of PBS and dispensed in wells of chamber slide, Lab-Tek, Nalgen Nunc ( $50 \mu 1 /$ well). After dryness of the cell suspension on the wells of the chamber slide, $100 \mu 1$ of cold $80 \%$ acetone in PBS was added to each well and kept at $20{ }^{\circ} \mathrm{C}$ for 20 minutes for fixation. After washing once with PBS, the fixed cells on the slide become ready for application of indirect immunofluroscent technique for detection of PPR viral antigen.

\section{Cells and virus}

Cultures of primary ovine embryo kidney cells and vero cell lines propagated in Eagles minimal essential medium (E-MEM) supplemented with 5-10\% of fetal calf serum (ICN Biomedicals, INC, Ohio, USA) plus pencillin sodium and streptomycin sulphate at final concentration of 100 $\mu \mathrm{l}$ and $100 \mathrm{ug} / \mathrm{ml}$ media were used for trails for virus isolation from the received tissue specimens.

Attenuated strain of PPRV, Nigerian $75 / 1$ of titer 6.0 $\log _{10} \mathrm{TCID}_{50} /$ vial kindly supplied by veterinary vaccine production centre, Riyadh, KSA was used as a control virus of known infectivity titer in immuno-capture ELISA.

\section{Laboratory investigations}

\section{Indirect fluorescent antibody (IFA) technique}

IFA was applied to visualize PPRV antigen in infected tissue specimens in guidness of Woldehiwet and Hussin (1994) as follows:

Fixed cells on the slides were incubated with a $1 / 5$ dilution of normal rabbit serum in $0.01 \mathrm{M} \mathrm{PBS}, \mathrm{pH} 7.4(50 \mu \mathrm{l} /$ well $)$ for 10 minutes at $37^{\circ} \mathrm{C}$. After thorough washing in PBS for 10 minutes at room temperature, standard strong anti-PPR sheep serum as well as standard PPR-negative sheep serum Pribright, UK, diluted 1:20 in PBS was added to the slides 
(50 $\mu \mathrm{l} /$ well). The slides were placed in humid box at $37^{\circ} \mathrm{C}$ for 1 hour. After washing twice, $50 \mu \mathrm{l}$ of $1 / 100$ dilution of fluorescin-conjugated rabbit IgG fraction to sheep IgG, Eappel, Organon, Teknika Crop, West Chester was added to each well and followed by incubation at $37{ }^{\circ} \mathrm{C}$ in humid box for 45 minutes. After another thorough twice washing, the slides were examined. Specificity of immunofluorescince was evaluated by first examining of cells exposed to standard negative PPR sheep serum.

\section{Immunocapture ELISA (IC-ELISA)}

Commercial Immunocapture ELISA kit for detection of PPRVand RPV-antigens in supernatant of the centrifuged tissue homogenate has been developed by Pribright laboratories, UK. Test kit was used according to the manufacture's recommendations. The test is based on the technique of Libeau et. al. 1994. A mouse monoclonal antibody (anti-PPRV/RPV) that attached to the microplate capture the virus present in tested sample. A second mouse monoclonal antibody (antiPPRV/RPV) which is biotinylated and is directed against the neuclocapside $(\mathrm{N})$ protein of the representive virus is used in conjugation with streptovidine-horseradishperoxidase conjugate to detect the capture antigen. Results were expressed as optical density values and related to a cut off value calculated according to manufacture's instruction.

\section{Virus isolation}

Trails for isolation of the causative virus from mouth-lesions scraping, spleen and lung tissue specimens throughout one passage in ovine embryo kidney cell cultures and three passage in vero cell cultures following the method of Taylor and Abegunde (1979).

\section{Competitive ELISA}

PPR competitive ELISA (C-ELISA) kit was prepared in collaboration between Cirad-emut laboratories and the animal production and health section of the joint FAO/IAEA. It used for detection of specific antibodies against PPRV in the serum samples collected from the affected animals. The test depends on inhibition of the bindings of mouse monoclonal antibodies to a PPRV-specific epitope in the presence of positive serum. Inhibition is detected as a reduction in the optical density reading obtained with the monoclonal antibody alone following the addition of peroxidase labeled anti-mouse conjugate and substrate/chromogen mixture. Tested sera demonstrating mean percent of inhibition (PI) values of $\geq 50 \%$ are considered to be positive and tested sera demonstrating mean PI values less than $50 \%$ are considered 
to be negative. The test is based on the technique of (Libeau, et. al. 1995)

\section{RESULTS}

\section{Clinical manifestations}

The most frequent clinical manifestations of PPR reported in 13 sheep flocks and 11 goat flocks with laboratory confirmed disease in Saudi Arabia between March and August 2004 are represented in table (1). From this table, it is clear the most common recorded clinical signs of PPR in the affected sheep and goats were fever, anorexia, diarrhea, nasal and ocular discharges dyspnea, and necro-ulcerative stomatitis at frequency rates of (100\%), (92.3\% and 100\%), (84.6\% and 100\%), (84.6\% and $90.9 \%),(61.5 \%$ and $81.8 \%)$, and $(69.2 \%$ and $54.5 \%)$ respectively.

\section{Necropsy findings}

At postmortem (PM) examinations, the most observed gross lesions in sheep and goats were pneumonia, enteritis, and inflammation of the abomasal mucosa in frequency rate of $(90.9 \%$ and $90 \%),(81.8 \%$ and $90 \%)$ and (18.2\% and 30\%) as shown in table (1).

Table 1: Frequency of PPR clinical signs and gross lesions reported in 13 sheep flocks and 11 goat flocks with laboratory confirmed disease in Saudi Arabia between March and August 2004.

\begin{tabular}{lrrrr}
\hline Signs/lesions & \multicolumn{2}{c}{ Sheep } & \multicolumn{2}{c}{ Goats } \\
& $\mathrm{n} / \mathrm{N}^{*}$ & $(\%)$ & $\mathrm{n} / \mathrm{N}$ & $(\%)$ \\
\hline$\quad$ Signs: & & & & \\
- Fever & $13 / 13$ & $(100)$ & $11 / 11$ & $(100)$ \\
- Anorexia & $12 / 13$ & $(92.3)$ & $11 / 11$ & $(100)$ \\
- Diarrhea & $11 / 13$ & $(84.6)$ & $11 / 11$ & $(100)$ \\
- Naso-ocular discharge & $11 / 13$ & $(84.6)$ & $10 / 11$ & $(90.9)$ \\
- Dyspnea & $8 / 13$ & $(61.5)$ & $9 / 11$ & $(81.8)$ \\
- Ulcerative stomatitis & $9 / 13$ & $(69.2)$ & $6 / 11$ & $(54.5)$ \\
- Coughing & $3 / 13$ & $(23.1)$ & $1 / 11$ & $(9.1)$ \\
- Oro-nasal encrustations & $1 / 13$ & $(7.7)$ & $1 / 11$ & $(9.1)$ \\
& & & & \\
$\quad$ Lesions: & & & & \\
- Pneumonia & $10 / 11$ & $(90.9)$ & $9 / 10$ & $(90)$ \\
- Enteritis & $9 / 11$ & $(81.8)$ & $9 / 10$ & $(90)$ \\
- Hemorrhagic enteritis & $4 / 11$ & $(36.4)$ & $4 / 10$ & $(40)$ \\
- Hemorrhages and necrosis in the abomasal mucosa & $2 / 11$ & $(18.2)$ & $3 / 10$ & $(30)$ \\
- Pleurisy & $1 / 11$ & $(9.1)$ & $0 / 10$ & $(0)$ \\
\hline
\end{tabular}

$*_{\mathrm{n}} / \mathrm{N}$ means number of animals with feature/number of clinical PPR-affected animals

Case fatality rate 
Data tabulated in table (2) revealed that the case fatality rates of PPR in the Southern region were (15.4\% and $24.2 \%)$, (40\% and $52.7 \%)$ and $(27.8 \%$ and $13.9 \%)$ in sheep and goats respectively in groups of animals aged 4, 6 and 9 months. While in the central region of the kingdom, the case fatalities were $9.1 \%, 18.4 \%$ and $23.3 \%$ among sheep.

Table 2: PPR-case fatalities in association of with age groups in sheep and goats with laboratory confirmed disease in SA between March and August 2004.

\begin{tabular}{|c|c|c|c|c|c|c|}
\hline \multirow[t]{2}{*}{ Location } & \multicolumn{3}{|c|}{ Sheep } & \multicolumn{3}{|c|}{ Goats } \\
\hline & Age & No. of affected flocks & case fatality rate & Age & No. of affected flocks & case fatality rate \\
\hline \multirow{3}{*}{$\begin{array}{l}\text { Southern region; } \\
\text { (Asser, Besha) }\end{array}$} & $4 \mathrm{~m}$ & (1) & $20 / 130(15.4 \%)$ & $4 \mathrm{~m}$ & (4) & $30 / 124(24.2 \%)$ \\
\hline & $6 \mathrm{~m}$ & (1) & $20 / 50(40 \%)$ & $6 \mathrm{~m}$ & (5) & $68 / 129(52.7 \%)$ \\
\hline & $9 \mathrm{~m}$ & (2) & $5 / 18(27.8 \%)$ & $9 \mathrm{~m}$ & (2) & $5 / 36(13.9 \%)$ \\
\hline \multirow{4}{*}{$\begin{array}{l}\text { Central region; } \\
\text { (Riyadh, Thadeq } \\
\text { AlKoyae, Hauta } \\
\text { Sedear) }\end{array}$} & $4 \mathrm{~m}$ & (1) & $1 / 11(9.1 \%)$ & & & \\
\hline & $6 \mathrm{~m}$ & (4) & $29 / 158(18.4 \%)$ & & & \\
\hline & $9 \mathrm{~m}$ & (3) & $33 / 148(22.3 \%)$ & & & \\
\hline & $1 \mathrm{y}$ & (1) & $0 / 10(0 \%)$ & & & \\
\hline
\end{tabular}

\section{Detection and isolation of PPRV}

Detection of PPR virus antigen by both IFA and IC-ELISA was successed in $100 \%$ of the tissue specimens (mouth scraping, lung and spleen), which collected from clinically affected sheep and goats, while trails for virus isolation from the same samples in cell cultures were unsuccessful (Table 3).

Table 3: Detection of PPRV in pre and post mortem samples collected from diseased sheep and goats

\begin{tabular}{lccc}
\hline Samples & $\begin{array}{c}\text { PPRV-antigen detection procedures } \\
\text { IFA }\end{array}$ & $\begin{array}{c}\text { PPRV isolation on tissue } \\
\text { culture }\end{array}$ \\
\hline Mouth scraping & $7 / 7$ & $7 / 7(4.7-6)^{* *}$ & $0 / 7$ \\
Lung & $4 / 4$ & $4 / 4(4.9-5.6)$ & $0 / 4$ \\
Spleen & $5 / 5$ & $5 / 5(4.7-6.2)$ & $0 / 5$ \\
\hline
\end{tabular}

IFA: immunofluorscent antibody technique

IC-ELISA: immuno-capture enzyme linked immunosorbent assay

$* *$ range of equivalent virus infectivity titer $\left(\log _{10} \mathrm{TCID}_{50}\right)$

\section{Serodiagnosis}

Table (4) represented the data of serodiagnosis of PPR in 6 flocks of sheep and 10 flocks of goats in central and southern regions of the kingdom, it indicated that, PPR-seropositive percentage ranges and 
mean values were $80 \%-100 \%(93.8 \%)$ and $46.7 \%-100 \%(76.6 \%)$ respectively in sera of clinical-PPR sheep and goats.

Table 4: Detection of PPRV-antibodies in sera of affected sheep and goats as tested by competitive ELISA

\begin{tabular}{lcccc}
\hline Animal species & \multirow{2}{*}{$\begin{array}{l}\text { No. of the } \\
\text { tested flocks }\end{array}$} & \multicolumn{3}{c}{ PPRV-antibodies } \\
\cline { 3 - 5 } & & +ve/tested samples & +ve \% & Range of +ve \% \\
\hline Sheep & 6 & $30 / 32$ & 93.8 & $80-100$ \\
Goats & 10 & $49 / 64$ & 76.6 & $46.7-100$ \\
\hline
\end{tabular}

\section{DISCUSSION}

The present study recorded an outbreak of PPR among sheep and goats in the central and southern regions of the Kingdom of Saudi Arabia between April-August 2004. During this outbreak, typical clinical signs of acute PPR including, fever, anorexia, diarrhea, mucopurulent nasal and ocular discharges, dyspnea and necro-ulcerative stomatitis; with a relatively high case fatality rates in lambs and kids aged 4 to 9 months; and gross lesions of pneumonia and enteritis were regulary recorded in PPR-affected sheep and goats flocks. Fatal acute PPR in sheep and goats is characterized by fever followed quickly by anorexia with inflammation of the upper and lower alimentary and respiratory tracts resulting in rapid development of ulcero-necrotic stomatitis, rhinitis, bronchopneumonia and enteritis which exhibited in signs of profuse, mucopurulent nasal and ocular discharges, encrustation on nares, eyes and lips, dyspnea and diarrhea (Braide, 1981). An outbreak of PPR characterized by fever, ocular and nasal discharge, coughing and sneezing, oral necrosis, diarrhea, enteritis and pneumonia was occurred in Ethiopian goats (Roeder, et. al. 1994).

In this reported outbreak, as a result of absence of vaccination against PPR in the affected sheep and goat flocks, restriction of the incidence of an acute clinical cases of PPR with case fatality rates ranged between 9.1 - 52.7\% in animals aged 4-9 months is likely reflects the presence of immunity against PPR in a high percentage of of adults due to previous exposure to the circulating virus that logically led to the occurrence of maternal immunity against the disease in majority of youngs until the $3^{\text {rd }}$ month after parturition. Absoultly no record of clinical PPR in lambs and kids less than 3 months of age in the affected flocks. However, case fatality rates were generally correlated with the 
age of diseased animals, it recorded values of (9.1-24.2\%) in animals of 4 months of age, (18.4-52.7\%) in animals of 6 months of age and (13.9$27.8 \%$ ) in animals of 9 months of age.

Age resistant to PPR in sheep and goats is absolutely not true but, in enzootic areas the percentage of sheep and goats with antibodies to PPR virus rises with age, and the risk of acute fatal PPR is clearly confined to animals less than 1 year of age. This result agree with the findings of many authors, who mentioned that the disease is most potent in animals aged less than 1 year and this probably due to field infection with some virulent strains of PPR hastened by some bacterial infections such as pneumonic pasterullosis and entertoxogenic E. coli (Losos, 1986; Radostitis et. al., 2000). This result is pointed out (1) PPR virus infection in regions of study appears to have been primarily through the continuous movement and contact between infected and susceptible animals, and (2) the importance of vaccination of lambs and kids against PPR in such regions at the $3^{\text {rd }}$ month of age.

In this study both PPRV-antigen and antibody assays were used to confirm the diagnosis of the disease. Approximately, seven affected sheep and goats flocks were diagnosed by PPRV-antigen detection in mouth scraping, spleen and lung tissue specimens using indirect fluorescent antibody (IFA) test and immuno-capture ELISA (ICELISA), and 16 affected flocks of sheep and goats were sero-diagnosed by detection of PPRV-antibodies using competitive ELISA (C-ELISA).

Sixteen tissue specimens were confirmed to be PPRV-antigen positive by both IFA and IC-ELISA. The obtained results suggest that (1) IFA test is a sensitive and reliable to demonstrate the cell associated PPRV-antigen; (2) commercial IC-ELISA is sensitive to detect and quantitate cell free PPRV-antigen; and (3) distribution of PPRV is seems to be equal in spleen, lung and mouth scraping where the recorded virus antigen concentrations were equivalent to virus titers ranged between 4.7 and $6.2 \log _{10} \mathrm{TCID}_{50}$. Immunocapture ELISA and immunofluorescence with virus specific monoclonal antibodies were used for detection and identification of PPR virus during an epizootic of PPR in northern India (Nanda, et. al., 1996).

On the opposite side, all tissue specimens subjected for PPRV isolation throughout one passage on primary cell cultures of ovine kidney and three passages on cell line cultures of vero cells were given negative results. There is no obvious explanation for the failure to isolate PPR virus than the possibility that it had lost viability during transportation and keeping of the samples, whatever is the explanation, 
IC-ELISA is a very specific, sensitive and rapid test for screening of PPRV antigen in tissue specimens, it can detect a very low titer $\left(06 \log _{10}\right.$ TCID $_{50}$ ) of virus (Libeau, et. al. 1994).

Monoclonal antibody-based competitive ELISA has been developed and used by Libeau, et. al. (1995); for the specific measurement of antibodies to PPR virus in sera of sheep and goats. In this report, as no available tissue specimens were received, serodiagnosis of PPR was carried out in 16 affected-flocks of sheep and goats by CELISA test. PPRV antibodies were detected in (40.7-100\%) of sera colleted from diseased sheep and goats. These high percentages of positive serum samples to PPRV antibodies are questionable but there are some points of concern in such cases, (1) serum samples were collected from individuals of PPR-infection suspicions between stage of illness and convalescence; (2) weaning age of PPR maternal antibodies in sheep and goats; (3) early development of PPRV-antibodies in the affected animals, and (4) history of vaccination against the disease in the flocks of study.

In conclusion, PPR outbreak among sheep and goats flocks in central and southern regions of the Kingdom mostly attributed to the presence of enzootic virulent strains of PPR virus, which could have circulate between the infected and susceptible animals in flocks of sheep and goats with no actual national vaccination regime against the disease.

\section{The present study recommended that:}

- An obligatory vaccination program against PPR virus infection should be applied for all flocks of sheep and goats allover the country.

- Lambs and kids should be vaccinated at $3^{\text {rd }}$ month of age, when the maternal antibodies decline.

- Legalization of the restriction of the animal movement should be applied for sheep and goats populations during the risk period of PPR in different localities of the country.

- Imported small ruminants should have been vaccinated against PPR at least 10 days before their shipping from the exporting countries using the standard homologous vaccines.

\section{REFERENCES}

Abdel Baky, M.H.; Abbas, A.M. and Al-Mujalli, D.M. (2001): Preliminary study of sero-surveillance of peste des petits ruminants antibodies in goats and sheep in Kingdom Saudi Arabia. Assiut Vet. Med. J.; Vol. 46, No. 91, 206-209. 
Abu-Elzein, E.M.E.; Hassanien, M.M.; Al-Afaleq, A.I.; Abdelhadi, M.A. and Honsawai, F.M.J. (1990): Isolation of peste des petits ruminants from goats in Saudi Arabia. Vet. Rec.; 27: 309.

Al-Naeem, A.; Abu Elzein, E.M. and Al-Afaleq, A.I. (2000): Epizootiological aspects of peste des petits ruminants and rinderpest in sheep and goats in Saudi Arabia. Rev. Sci. Tech.; 19 (3): 855-858.

Braide, V.B. (1981): Peste des petits ruminants. A review. World Anim. Rev.; 39:25-28.

Diallo, A.; Barrett, T.; Barbron, M.; Meyer, G. and Lefevre, P.C. (1994): Cloning of the nucleocapsid protein gene of peste-despetits-ruminants virus: relationship to other morbilliviruses. J. Gen. Virol.; 75 ( Pt 1): 233-237.

Gibbs, E.P.J.; Taylor, W.P.; Lawman, M.J.P. and Bryant, J. (1979): Classification of peste des petits ruminants virus as the fourth member of the genus Morbillivirus. Intervirology, II, 268-274.

Hamdy, F.M.; Dardiri, A.H.; Breese, S.S. and Jr, DeBoer C.J. (1975): Immunologic relationship between rinderpest and peste des petits ruminants viruses. Proc. Annu. Meet. U S Anim. Health Assoc. 1975; (79): 168-179.

Libeau, G.; Diallo, A.; Colas, F. and Guerre, L. (1994): Rapid differentiatial diagnosis of rinderpest and peste des petits ruminants using an immunocapture ELISA. Vet. Rec.; 134: 300-304.

Libeau, G.; Prehaud, C.; Lancelot, R.; Colas, F.; Guerre, L.; Bishop, D.H. and Diallo A. (1995): Development of a competitive ELISA for detecting antibodies to the peste des petits ruminants virus using a recombinant nucleoprotein. Res. Vet. Sci.; 58 (1): $50-55$.

Losos, G.J. (1986): Infectious tropical diseases of domestic animals. Published with the international development research centre Canada. pp. 549-558.

Nanda, Y.P.; Chatterjee, A.; Purohit, A.K.; Diallo, A.; Innui, K.; Sharma, R.N.; Libeau, G.; Thevasagayam, J.A.; Bruning, A.; Kitching, R.P.; Anderson, J.; Barrett, T. and Taylor W.P. (1996): The isolation of peste des petits ruminants virus from northern India. Vet. Microbiol.; 51 (3-4): 207-216. 
Özkul, A.; Akca, Y.; Alkan, F.; Barrett, T.; Karaoglu, T.; Dagalp, S.B.; Anderson, J.; Yesilbag, K.; Cokcaliskan, C.; Gencay, A. and Burgu, I. (2002): Prevalence, Distribution, and Host Range of Peste des petits ruminants virus, Turkey. Emergency infectious diseases Vol. 8, No. 7

Radostits, O.M.; Gay, C.C.; Blood, D.C. and Hinchcliff, K.W. (2000): Veterinary medicine, $9^{\text {th }}$ ed., W.B. Saunders Company Ltd, London, New York, Philadelphia, San Francisco, St Louis, Sydney. pp. 1077-1079.

Roeder, P.L.; Abraham, G.; Kenfe, G. and Barrett, T. (1994): Peste des petits ruminants in Ethiopian goats. Trop. Anim. Health Prod; 26: 69-73.

Shaila, M.S.; Shamaki, D.; Forsyth, M.; Diallo, A.; Goatley, L., and Kitching P, (1996): Geographic distribution and epidemiology of peste des petits ruminants viruses. Virus Res.; 43: 149-153.

Taylor, W.P. (1984): The distribution and epidemiology of peste des petits ruminants. Prev. Vet. Med; 2: 157-166.

Taylor, W.P. and Abegunde, A. (1979): The isolation of peste des petits ruminants from Nigerian sheep and goats. Res. Vet. Sci.; 26: 94-96.

Taylor, W.P.; Al Busaidy, S. and Barrett, T. (1990): The epidemiology of peste des petits ruminants in the Sultanate of Oman. Vet. Microbiol.; 22 (4): 341-352.

Woldehiwet, Z. and Hussin, A.A. (1994): Border disease virus in lymphocyte subpopulations of persistently infected sheep. Veterinary Immunology and Immunopathology, 42: 127-135. 